\title{
Correction for modelling the COVID-19 pandemic in context: an international participatory approach
}

Aguas R, White L, Hupert N, et al. Modelling the COVID-19 pandemic in context: an international participatory approach. BMJ Glob Health 2020;5:e003126. doi: 10.1136/ bmjgh-2020-003126.

This article has a correction. The group in South Africa has been using their own models and not the COVID-19 Modelling Consortium model. Their inclusion in the manuscript was an error.

Open access This is an open access article distributed in accordance with the Creative Commons Attribution 4.0 Unported (CC BY 4.0) license, which permits others to copy, redistribute, remix, transform and build upon this work for any purpose, provided the original work is properly cited, a link to the licence is given, and indication of whether changes were made. See: https://creativecommons.org/licenses/by/4.0/.

C Author(s) (or their employer(s)) 2021. Re-use permitted under CC BY. Published by BMJ.

BMJ Global Health 2021;6:e003126corr1. doi:10.1136/bmjgh-2020-003126corr1

A) Check for updates 